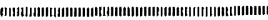

\title{
高純度フェライト系ステンレス鋼量産方式の開発*
}

\author{
岩 岡 昭 二**.大 橋 延 夫***

\section{Development of Mass Production Process for High Purity Ferritic Stainless} \\ Steel
}

\author{
Shoji IwAOKA and Nobuo OHASHI
}

\section{1. まえがき}

オーステナイト系ステンレス鋼の欠点である, 主とし て応力腐食割れを解消する見地から, 極低炭素, 極低窒 素とした高 $\mathrm{Cr} フ ェ ラ イ ト$ 系ステンレス鋼が注目されて いる. 1969 年, 米国の AIRCO 社は EBR (Electron Beam Remelting）を利用して製造した， $\simeq \simeq 20 \mathrm{ppm}$, $\mathrm{N} \simeq 70 \mathrm{ppm}$ の $26 \% \mathrm{Cr}-1 \% \mathrm{Mo}$ 鋼を， E-Brite $26-1$ と 名付けて商品化した1). 国内でも, 昭和電工で真空誘導 溶解して製造した $30 \% \mathrm{Cr}-2 \% \mathrm{Mo}$ 鋼，いわゆる $\mathrm{SHO}$ MAC 30-2 が発表されている2). これらは, 高 $\mathrm{Cr}$ 鋼 の脱炭脱窒が困難であるため，精選された特殊材料と特 殊な精錬法を用いなければならず量産プロセスとはなり 難い. 一方, VOD (Vacuum Oxygen Decarburization) 法は, 開発された当初から, 真空処理の利点のために, 低炭素, 低窒素鋼の 製造に適したものと考えられてき た.この面の研究は盛んであり, 最近では片山らの研 究3)がとくに詳しい. しかし，従来技術では $\mathrm{C} ， \mathrm{~N}$ とも に，50 ppm 程度に下げるのが限界と見られていた。

著者らも，1971 年西宮工場に VOD 設備を導入して 以来，極低炭素化を目指して種々の実験を続けてきた が，最近になつて，20\% 以上の高 $\mathrm{Cr}$ 鋼でも，30 ppm 以下まで脱炭できる技術を開発することができた。これ は, Ar ガスの大量使用による, 溶鋼の強攪拌によるも ので, SS-VOD 法と呼ばれる. 以下, この技術と, そ の開発途上で見出された， $2 ， 3$ の興味ある知見につい て紹介したい。

\section{2. 高 $\mathbf{C} \mathbf{r}$ 鋼の真空脱炭, 脱窒反応}

減圧下における溶鋼の脱炭と脱窒反応平衡は，(1)〜 (4)式で記述されている4)5).

$\mathrm{Cr}_{2} \mathrm{O}_{3}+3 \underline{\mathrm{C}}=2 \underline{\mathrm{Cr}}+3 \mathrm{CO}$.

$$
=-40990 / T+25.83
$$

$$
N=1 / 2 \mathrm{~N}_{2}
$$

$$
\log K_{2}\left(=p_{\mathrm{N}_{2}}{ }^{1 / 2} / a_{\mathrm{N}}\right)=188 / T+1.248
$$

$$
\pm 21.86 / T
$$

Cr は， C， OおよびNの活量を著しく下げるので，普 通鋼と比べると高 $\mathrm{Cr}$ 鋼の脱炭, 脱窒は困難である. 相

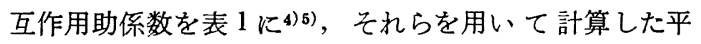
衡濃度を図 1 と 2 に示す.

高 $\mathrm{Cr}$ 溶鋼では, その上, 成分元素の移動速度も小さ いといわれ6), 平衡, 速度両面での不利を強いられる.

また, 従来の研究報告では, 真空脱炭処理中の $\mathrm{C}$ 含有 量がある有限の值に漸近する挙動がある。いわゆる“見 かけの平衡値”といわれているもので, 脱炭反応に何ら 表 1 相 互 作 用 助 係数

\begin{tabular}{c|c|c|c}
\hline & $e_{\mathrm{O}}^{\mathrm{Cr}}$ & $e_{\mathrm{C}}^{\mathrm{Cr}}$ & $e{ }_{\mathrm{N}}^{\mathrm{Cr}}$ \\
\hline $1600^{\circ} \mathrm{C}$ & -0.0519 & -0.023 & -0.045 \\
\hline $1700^{\circ} \mathrm{C}$ & -0.0416 & -0.021 & - \\
\hline
\end{tabular}

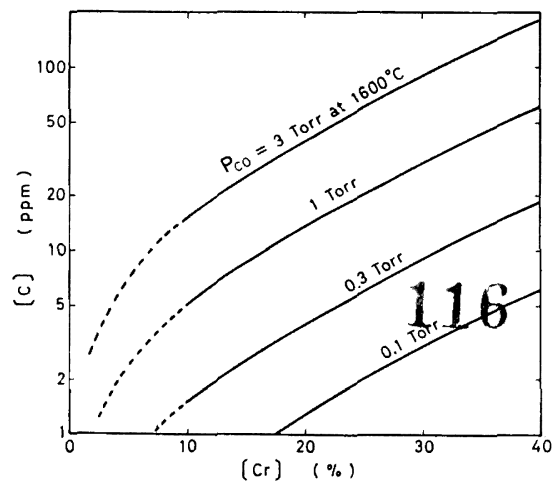

図 $1 \mathrm{Cr}$ 鋼の脱炭平衡 $\left(a_{\mathrm{Cr}_{2} \mathrm{O}_{3}}=1\right)$

* 昭和 52 年 4 月本会講演大会にて発表 昭和 54 年 6 月 14 日受付 (Received June 14, 1979) (依頼技術トビックス)

** 川崎货鉄(株)千葉製鉄所（Chiba Works, Kawasaki Steel Corp., 1 Kawasaki-cho Chiba 260)

*** 川崎製鉄(株)技術研究所 工博 (Research Laboratories, Kawasaki Steel Corp.) 


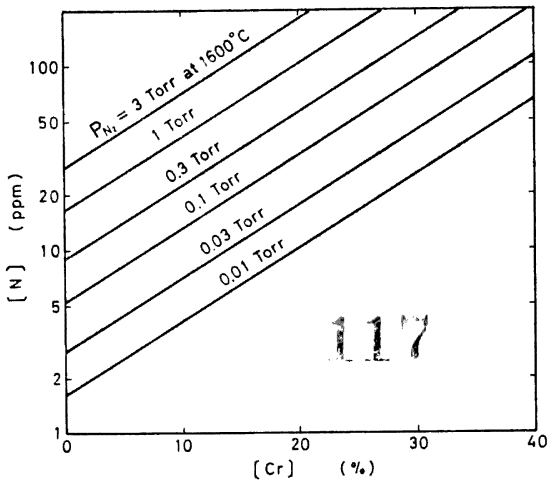

困 $2 \mathrm{Cr}$ 鋼の脱空平衡

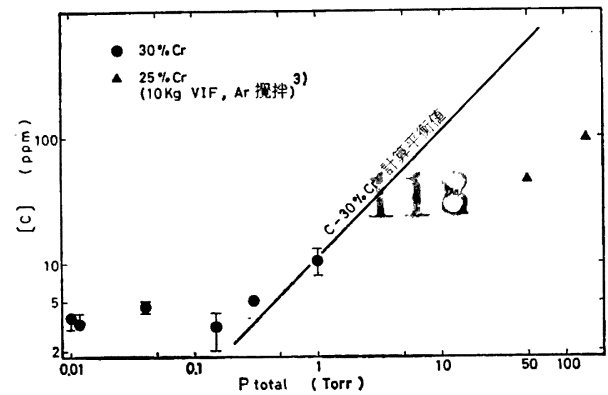

因 $320 \mathrm{~kg}$ 真空誘導灿における $30 \% \mathrm{Cr}$ 鋼の $\mathrm{C}$ 到達值 $\left(1700^{\circ} \mathrm{C}, 60 \mathrm{~min}\right)$

かの限界があると考えるものである.工業規模の普通鋼 真空処理では, $[\mathrm{C}] \cdot[\mathrm{O}]$ 濃度積が, $p_{\mathrm{CO}}=0.01 \sim 0.1$ atm との平衡に相当するレペルまで脱炭が進む7)。しか し，高 $\mathrm{Cr}$ 鋼では，この見かけの平衡 $p_{\mathrm{Co}}$ がもう少し 低い3).

著者らは，この見かけの平衡値に疑問を持ち, 実験室 的検討を試みた. すなわち, $20 \mathrm{~kg}$ の真空誘導溶解炉 で，30\% をでの高 $\mathrm{Cr}$ 溶鋼の脱炭実験を行い，次の結 果を得だ).

(1) $30 \% \mathrm{Cr}$ 鋼でも， [C]，100 ppm から出発し て，60 min で $10 \mathrm{ppm}$ 以下の十分低值まで脱炭できる.

（2）そのためには，0.5Torr 程度の減圧に保つ必要 がある. しかし, 図 3 に示すよらに8), これ以上の高真 空にしても [G]到達値には影響しない.

(3) $1650^{\circ} \mathrm{C}$ 以上の高温での脱炭は容易であるが, これ以下の低温では, 浴面に酸化物膜を生じ脱炭が遅く なる現象がある。

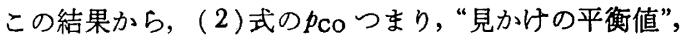
に真の平衡という意味が 無い訳で，高 $\mathrm{Cr}$ 鋼では，真 の “ $p_{\mathrm{co}}$ ”が低くなり脱炭の到達值も十分低いと確信し た. 問題は速度にあると考えられ，強擤汼による脱炭助 長の方向を採用した.
VOD では，次の脱窒挙動が知られている.

(1) 脱窒は，脱炭の初期に急激に進む.

（2）初期N含有量は, 到達值にほと儿ど影響しない.

（3）処理末期には，全く脱窒しないか，わずかに吸 窒する.

すなわち，見かけ上の高次の反応速度は反応律速を示 唆する9）ものであり，とくに極低窒素領域での反応速度 の改善が肝要である，単に強挸汼のみでなく，(1)反応 面での妨害元素 [O] の影響除去 ${ }^{10)} ，(2)$ 高炭素による $a N$ の增大効果などが検討された. ただし， $\mathrm{Si}$ 脱酸後 の脱窒がほとんど進行しないことから，（1）に関する期 待は持てない。

\section{VOD における脱宸と脱窒の改善法}

以下, 50 tVOD 炬に拈ける，脱炭および脱窒の促進条 件について述べる，用いた装置は，表 2 の通り，標準仕 様であるが，Ar ガス流量は最大 $2.4 \mathrm{~N} \mathrm{~m}^{3} / \mathrm{min}$ まで, 大量供給を可能にしている。

VOD は，便宜上次の 2 期に分けて考える. また，添 字，I，IIで各期を，o，fでそれぞれの起点と終点を 表わすことにする.

I 期 : [C] : 0.8 2.0\% から，20〜40 Torr の減圧 下で酸素吹精する脱炭期. 酸素吹精終了点の [C]

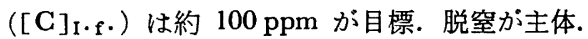

III期 : 酸素を止めて後の真空脱炭期. 到達真空度 0.5

Torr, 最終 $[\mathrm{C}]_{\mathrm{II} \cdot \mathrm{f} . \leqq} \leqq \mathrm{ppm}$ とする.

\section{1 脱炭反応の促進}

II 期の実際の脱炭挙動は見かけ上 1 次反応速度式で表 わされ，(5)式となる.

$$
\left([\mathrm{C}]-[\mathrm{C}]_{\mathrm{i}}\right) /\left([\mathrm{C}]_{0}-[\mathrm{C}]_{1}=\exp \left(-k_{\mathrm{c}} \cdot t\right)\right.
$$

ここで， $[\mathrm{G}]_{1}$ : 見かけの平衡値, $k_{\mathrm{c}}$ : 見かけの速度定数 $\left(\mathrm{s}^{-1}\right), t:$ 時間 $(\mathrm{s}),[\mathrm{C}]_{0}:$ 処理開始点の $\mathbf{C}$ 濃度 $(=$

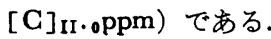

$[\mathrm{G}]_{1}$ がいわゆる見かけの平衡値（もしくは漸近值） で，実験值に最もよく適合するように(5)式から $[\mathrm{C}]_{1}$ と $k_{\mathrm{c}}$ を求める.

開発初期の実験では，条件不適で $[\mathrm{C}]_{1}>10 \mathrm{ppm}$ とな 表 2 電気炉, VOD

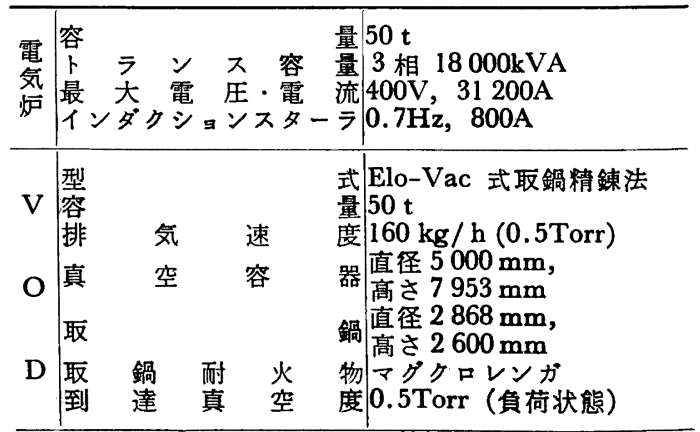




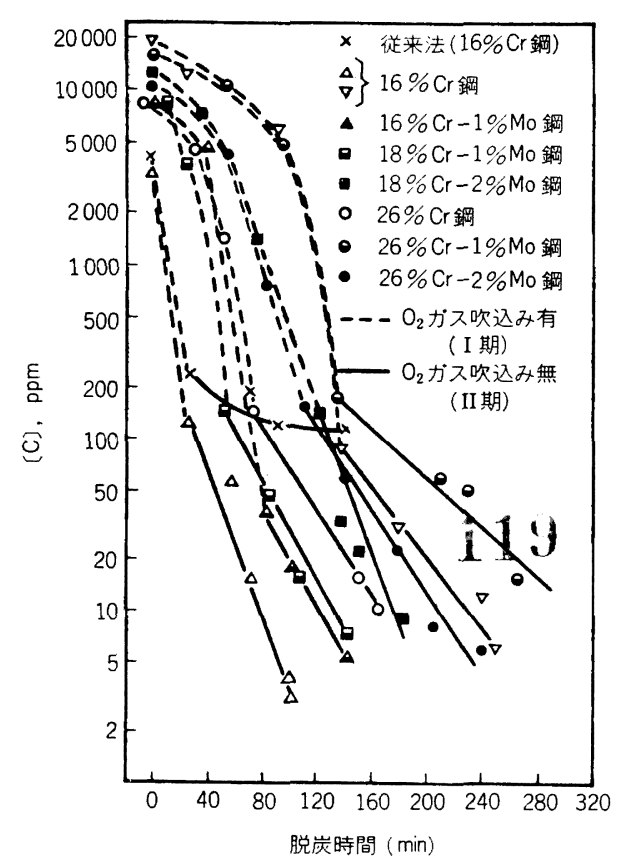

図 4 SS-VOD における脱炭挙動

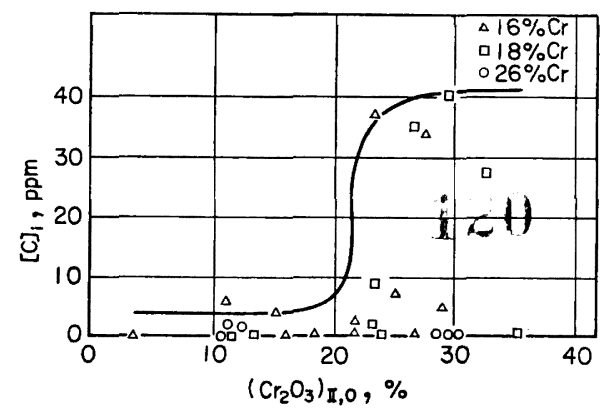

図 $5[\mathrm{G}]_{1}$ と $\left[\mathrm{Cr}_{2} \mathrm{O}_{3}\right)_{\mathrm{II}, 0}$ との関係

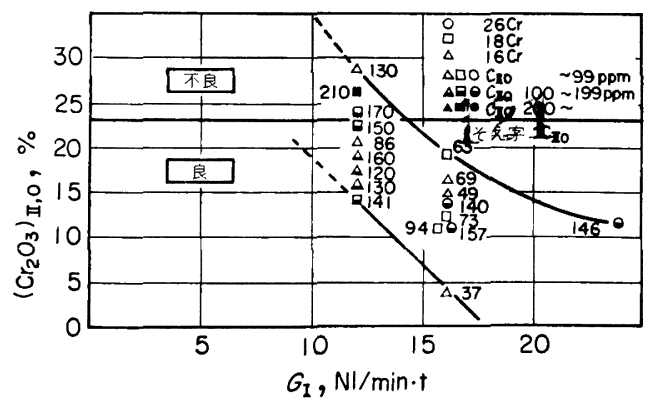

四 $6 \quad\left(\mathrm{Cr}_{2} \mathrm{O}_{3}\right)_{\mathrm{II} \cdot 0}$ に及ほす $G_{\mathrm{I}}$ の影響

る例が多かつた，しかし，適正操業が行われる限り，因

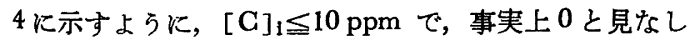
得る。これらの $[\mathrm{C}]_{1}$ と $k_{\mathrm{c}}$ を通して, 操業法改善の手掛
りを求めた。

（1） $[\mathrm{C}]_{\mathrm{i}}$ に影響する要因に関して

$[\mathrm{C}]_{1}$ に影響する要因は数多く予測されたが，因 5 に 示すよらに, II 期前のスラグ中 $\mathrm{Cr}_{2} \mathrm{O}_{3}$ 含有量 $\left(\mathrm{Cr}_{2} \mathrm{O}_{3}\right)_{I I \cdot 0}$ の影響が顕著であつた.これが $23 \%$ を越すと $[\mathrm{C}]_{1}$ か 高くなる場合が多い。

$\left(\mathrm{Cr}_{2} \mathrm{O}_{3}\right)_{\mathrm{II} \cdot 0}$ は, 図 6 に示すように, I 期の $\mathrm{Ar}$ 流量, $G_{\mathrm{I}}(\mathrm{Nl} / \mathrm{min} \cdot \mathrm{t})$ で決まる。つまり，送酸時に強摫拌を 行い, $\mathrm{Cr}_{2} \mathrm{O}_{3}$ の生成を抑えることが， II期の脱炭限界を 下げるといら，予期せ結果であつた。 図中，添字は I 期終点の $[\mathrm{C}]_{\mathrm{I} \cdot \mathrm{J}}$ であるが， $G_{\mathrm{I}}$ が大さいと， $[\mathrm{C}]_{\mathrm{I} \cdot \mathrm{J}}$ も 低い，あるいは終点制御が安定しているといえる.

II 期のAr 流量, $G_{\mathrm{II}}$ や，スラグ量, 真空度, あるい は Cr p Mo などの成分濃度も， $[\mathrm{C}]_{1}$ に実質上影響し ない.

（2） $k_{\mathrm{c}}$ に影響する要因に関して

$k_{\mathrm{c}}$ についても [C] 1 と同様で, 図7 に示すように, $\left(\mathrm{Cr}_{2} \mathrm{O}_{3}\right)_{\mathrm{II} \cdot \mathrm{J}}$ の増化にともない， $k_{\mathrm{c}}$ が減少する， $G_{\mathrm{II}}$ は, 図 8 に示した流量範囲で $k_{\mathrm{c}}$ にほとんど影響しない，実 験条件の範囲で, 温度 $\left(1600 \sim 1720^{\circ} \mathrm{C}\right)$, 真空度 $(0.5 \sim$ 1.5 Torr $), \mathrm{Cr}$ 含有量 $(16 \sim 26 \%$ ) 等の影響は認められ なかつた。

当初, 高 $[\mathrm{O}]$ 含有量が脱炭促進につながるとの期待を 持ら，II期中に少量の酸素供給を試みた例がある. 結果

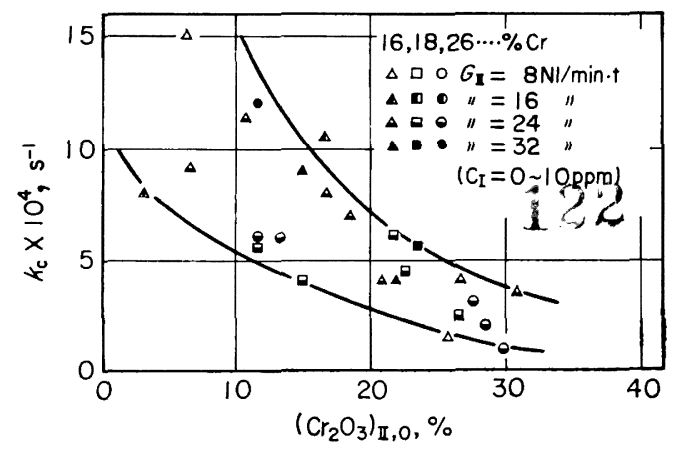

図 $7 k_{\mathrm{c}}$ に及ほす $\left(\mathrm{Cr}_{2} \mathrm{O}_{3}\right)_{\mathrm{II}, 0}$ の影響

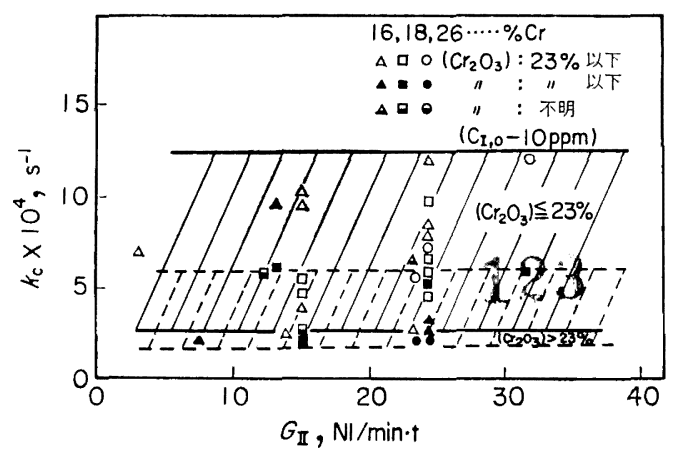

図 8 k $k_{\mathrm{c}}$ に及ほす寸 $G_{\mathrm{II}}$ の影響 
表 $3 \mathrm{SS}-\mathrm{VOD}$ II 期でのスラグ組成の変化

\begin{tabular}{|c|c|c|c|c|c|c|c|c|c|}
\hline \multirow{2}{*}{ ヒート } & \multirow{2}{*}{ 時 期 } & ス & j グ & 成 & \multirow{2}{*}{ スラグ相 } & \multirow{2}{*}{ 流 動 性 } & \multirow{2}{*}{$\begin{array}{c}T_{\text {II, }} \\
\left({ }^{\circ} \mathrm{C},\right)^{-1}\end{array}$} & \multirow{2}{*}{$\begin{array}{c}\mathrm{C}_{\mathbf{i}} \\
(\mathrm{ppm})\end{array}$} & \multirow{2}{*}{$\left(\begin{array}{c}K \\
\mathrm{~s}^{-1}\end{array}\right)$} \\
\hline & & $\mathrm{Cr}_{2} \mathrm{O}_{3}$ & $\mathrm{SiO}_{2}$ & T.Fe & & & & & \\
\hline 例 1 & $\begin{array}{l}\mathrm{II}, 0 \\
\text { II, f }\end{array}$ & $\begin{array}{l}16.5 \\
24.2\end{array}$ & $\begin{array}{l}31.5 \\
27.5\end{array}$ & $\begin{array}{l}2.1 \\
1.5\end{array}$ & $\begin{array}{ll}\text { 液 } & \text { 相 } \\
\text { 液 } & \text { 相 }\end{array}$ & $\begin{array}{ll}\text { 最 } & \text { 良 } \\
\text { 良 }\end{array}$ & 1595 & 0 & $7.70 \times 10^{-4}$ \\
\hline 例 2 & $\begin{array}{l}\text { II, } 0 \\
\text { II, f }\end{array}$ & $\begin{array}{l}29.5 \\
33.5\end{array}$ & $\begin{array}{l}33.5 \\
24.2\end{array}$ & $\begin{array}{l}2.3 \\
2.2\end{array}$ & $\begin{array}{ll}\text { 液 } & \text { 相 } \\
\text { 液 相 }\end{array}$ & 不良良 & 1595 & 0 & $2.22 \times 10^{-4}$ \\
\hline 例 3 & $\begin{array}{l}\mathrm{II}, 0 \\
\text { II, f }\end{array}$ & $\begin{array}{l}29.7 \\
33.0\end{array}$ & $\begin{array}{l}35.0 \\
27.5\end{array}$ & $\begin{array}{l}2.9 \\
4.7\end{array}$ & $\begin{array}{ll}\text { 液 } & \text { 相 } \\
\text { 固 }\end{array}$ & 良 & 1592 & 40 & $8.41 \times 10^{-4}$ \\
\hline
\end{tabular}

表 4 実験結果から推測される CO 反応サイト ( $\bigcirc$ 可能性大, $\triangle$ 可能性中, $\times$ 可能性小)

\begin{tabular}{|c|c|c|c|c|}
\hline \multirow{2}{*}{$\begin{array}{l}\text { 実験結果 } \\
{[\mathrm{C}]-[\mathrm{O}]} \\
\text { 反応サイト } \\
\end{array}$} & \multirow{2}{*}{$\begin{array}{l}K \text { 渵 } G_{11} \\
\text { に依存し } \\
\text { ない }\end{array}$} & \multicolumn{2}{|c|}{$\begin{array}{l}\left(\mathrm{Cr}_{2} \mathrm{O}_{3}\right)_{11,0} \text { が小さく } \\
\text { なれば } K \text { が大きくなる }\end{array}$} & \multirow{2}{*}{$\begin{array}{l}\text { スラグ無 } \\
\text { し脱炭で } \\
\text { は } K \text { が著 } \\
\text { しく小さ } \\
\text { くなる }\end{array}$} \\
\hline & & 酸素供給良 & 流動性良 & \\
\hline \multirow{6}{*}{$\begin{array}{l}\text { スラグと溶鋼 } \\
\text { 界面 } \\
\text { 自由表面 } \\
\text { Arガス気泡 } \\
\text { 耐火物壁 } \\
\text { 溶鋼からの均 } \\
\text { 一核生成 } \\
\text { キャビティ }\end{array}$} & $\Delta$ & 0 & 0 & 0 \\
\hline & $\triangle$ & $x$ & $\triangle$ & $\times$ \\
\hline & $x$ & $x$ & $x$ & $x$ \\
\hline & $\Delta$ & $x$ & $\Delta$ & $x$ \\
\hline & 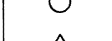 & $x$ & $x$ & $x$ \\
\hline & $\Delta$ & $x$ & $x$ & $x$ \\
\hline
\end{tabular}

は, [O]を高值となし得るが, 脱炭がむしろ抑制されるも のであつた． II 期中に $\left(\mathrm{Cr}_{2} \mathrm{O}_{3}\right)$ の増加が著しく，スラグ が固化して塊状となるのが脱炭阻害要因と考えられた。

(3) $[\mathrm{C}]_{1}$ の物理的意味について

前述のように, $[\mathrm{C}]_{1} \simeq 0$ となる例が存在することは $[\mathrm{C}]_{1}$ に，平衡論的に意味が無いことを示す.ゆえにこ れは, 速度論的に現われる見かけの現象と解釈するのが 妥当である.

II期では，温度降下にともなら[O]の減少がある.こ れは $\mathrm{Cr}_{2} \mathrm{O}_{3}$ の析出を意味し, 表 3 のようなスラグ組成 変化にも対応する. 図 7 のように, $k_{\mathrm{c}}$ が $\left(\mathrm{Cr}_{2} \mathrm{O}_{3}\right)$ に 依存するものであれば, $k_{\mathrm{c}}$ が漸次減少することになる. このような場合, もはや反応は一次形を取らず高次とな るが, かりに有効の処理時間内で, 高次の反応を 1 次と 見なして近似すると，見かけ上の漸近值 $[\mathrm{G}]_{1}$ が高值と なつてしまう. 問題が $[\mathrm{C}]_{1}$ ではなく，k $k_{\mathrm{c}}$ にあり，これ を十分大とすることができれば， $[\mathrm{G}]_{\mathrm{i}}$ も自然と低値に なることが確かめられた.

高 $\mathrm{Cr}$ 鋼といえどる, 到達可能な $[\mathrm{C}]$ 值は普通鋼とさ して変わらないといらのは興味ある知見である。

(4) $\left(\mathrm{Cr}_{2} \mathrm{O}_{3}\right)$ の作用について

スラク中の $\mathrm{Cr}_{2} \mathrm{O}_{3}$ 含有量がII期の脱炭に影響する理 由については，また結論を得ていない，しかし，考えら れる反応サイトとしては，表4のようなものがある. 流 動性がよい，低 $\left(\mathrm{Cr}_{2} \mathrm{O}_{3}\right)$ 含有量のスラグの影響として
表 5 除涬により湯面を露出しやすくした実験例

\begin{tabular}{l|c|c}
\hline & $\begin{array}{c}k_{\mathrm{c}} \times 10^{4} \\
(\mathrm{~s}-1)\end{array}$ & $\begin{array}{c}{[\mathrm{G}]_{\mathrm{II}, \mathrm{f}}} \\
(\mathrm{ppm})\end{array}$ \\
\hline 除涬実験 & 0.7 & 109 \\
\hline 標準 SS-VOD & $5 \sim 10$ & $<10$ \\
\hline
\end{tabular}

は, (1) 取鍋周辺に寄りやすく, 溶鋼の表面が露出しや すいという効果が，または(2)スラクによる物理的，化 学的な脱炭促進作用, が注目される。

(1)の脱炭機構では反応速度が溶鋼の自由表面積に依 在するものであるとの仮定に立ち，II期前の完全除涬の 試験を行つた. その結果は, 表 5 に示すよらに, 最終值 $100 \mathrm{ppm}$ 程度にとどまる例がある。 また，本機構では $k_{\mathrm{c}}$ が $G_{\mathrm{II}}$ の影響を大きく受けることが予想されるが， 実際には $G_{\mathrm{II}}$ が $k_{\mathrm{c}}$ に顕著な影響を持たないといら前述 の結果とも考え合わせ，自由表面の現象たけでは説明し 難い.

(2)の考え方においては, $\mathrm{Cr}_{2} \mathrm{O}_{3}$ 含有量の小さい, 寸 なわち, $\mathrm{SiO}_{2}$ 含有量の高いスラグと接する場合に $\mathrm{CO}$ 発生が助長される. あるいは, $\mathrm{Cr}_{2} \mathrm{O}_{3}$ 含有量の低い, 流 動性のよいスラグは分散して鋼中に眯濁し, CO 発生の サイトを増す，などの可能性がある. $\mathrm{SiO}_{2}$ 系耐火物と 接した場合，他の耐火物の場合より CO 発生が大きい11) 現象が知られているので, 前者 (2)の作用も有り得る. この点については, 現象を解明して, より一層の改善を 図る予定である.

\section{2 脱窒反応の促進}

（1）脱窒反応に影響する要因について

最終值 $[\mathrm{N}]_{\mathrm{II} \cdot \mathrm{J}}$ に対する影響の最大のものは, 処理前 の $[\mathrm{C}]_{\mathrm{I} \cdot 0}$ である. 図 9,10 に示したように,これが 0.8 \% 以上であれば，鋼種その他の条件によらず， $[\mathrm{N}]_{\mathrm{II} \cdot \mathrm{J}}$ $\leq 40 \mathrm{ppm}$ とすることができる.

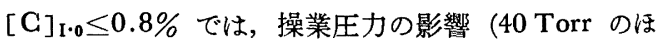
らが 20 Torr の [N] Ir·占 より高い) や, $\mathrm{Cr}$ 含有量 ( $[\mathrm{N}]_{\mathrm{II} \cdot \mathrm{J}}$ が高 $\mathrm{Cr}$ ほど高值) の影響が見られる.しか 乙, 実験条件の範囲で, 処理前 $[\mathrm{N}]_{\mathrm{I} \cdot 0}$ や， $G_{\mathrm{I}}$ の影響は 認められない. 


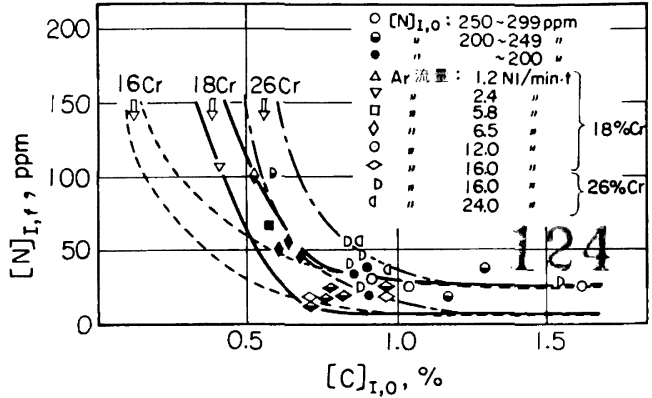

因 $9[\mathrm{C}]_{\mathrm{I}, 0}$ と $[\mathrm{N}]_{\mathrm{I}, \mathrm{f}}$ との関係 (18〜26\% Gr 鋼)

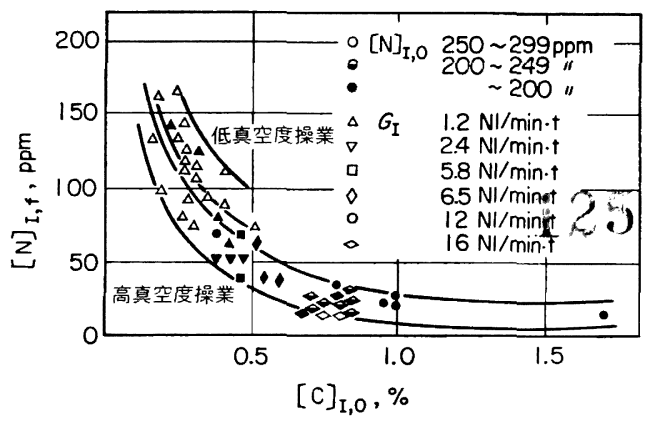

図 $10 \quad 16 \% \mathrm{Cr}$ 鋼の脱窒に及ほす真空度の影響

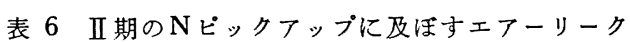
の影響

\begin{tabular}{c|c|c|c|c}
\hline $\begin{array}{l}\text { エフーリー } \\
\text { 速度 } \\
\left(\mathrm{Nm}^{3} / \mathrm{min}\right)\end{array}$ & 鋼 種 & $\begin{array}{c}\text { 真空度 } \\
(\mathrm{Torr})\end{array}$ & $\begin{array}{c}\text { 処理時間 } \\
(\mathrm{min})\end{array}$ & $\begin{array}{c}\mathrm{N} \text { 挙動 } \\
(\mathrm{ppm})\end{array}$ \\
\hline 1.613 & $\begin{array}{l}18 \mathrm{Cr} \\
26 \mathrm{Cr}\end{array}$ & $\begin{array}{l}0.5 \\
0.5\end{array}$ & $\begin{array}{l}70 \\
90\end{array}$ & $\begin{array}{c}30 \rightarrow 33 \\
53 \rightarrow 82\end{array}$ \\
\hline 0.564 & $\begin{array}{l}18 \mathrm{Cr} \\
26 \mathrm{Cr}\end{array}$ & $\begin{array}{l}0.5 \\
0.5\end{array}$ & $\begin{array}{c}80 \\
126\end{array}$ & $\begin{array}{c}25 \rightarrow 20 \\
43 \rightarrow 40\end{array}$ \\
\hline
\end{tabular}

$[\mathrm{N}]_{\mathrm{II} \cdot \mathrm{J}}$ は，空気の洩孔込み速度に依存する ${ }^{3)}$. 著者 らも, リーク量を $1 / 3$ に減らしたところ, 表 6 に示すよ らに末期の $[\mathrm{N}]$ 増加現象は完全に止つた. [N] $\mathrm{I} \cdot \mathrm{J}$ は， $p_{\mathrm{N}_{2}}$ の 0.06 Torr に相当する低值であり, 僅かな $\mathrm{N}_{2}$ ガ スの混入も許されない.

(2) 脱窒反応速度について

脱窒はI期の激しい,CO ガス発生時にのみ進む。見 かけの反応次数は明らかに 1 より大きい。そこで，CO 気泡による洗浄作用を仮定して ${ }^{12)}$ ，次のモデル計算によ る記述を試みた。

発生する CO および Ar ガス気泡中に, 一定飽和度

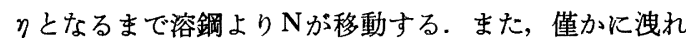
込む空気のためにN吸収があり，濃度変化は両者のバラ ンスで決まるものとする.

このモデルは，2 次反応速度の形をとり，操業諸要因 の影響を適切に説明することができた、計算結果の 1 例

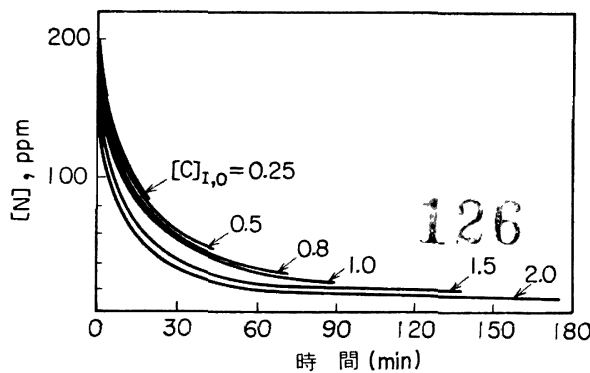

図 11 脱窒におよほすす $[\mathrm{G}]_{\mathrm{I}, 0}$ の影響 （モデル計算）

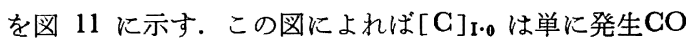
ガス量としてばかりでなく， $a_{\mathrm{N}}$ を高めることにより 脱窒に寄与していることがわかる．本図によつても， $[\mathrm{C}]_{\mathrm{I} \cdot 0} \geq 0.8 \%$ であれば最終値が十分低くなる現象は明 白である.

\section{4. 製 造 工 程}

上記の脱炭および脱窒法の確立の後，次のような，高 純度高 $\mathrm{Cr}$ フェライト系ステンレス鋼の製造工程を完成 した.

\section{1 電気炉}

表 2 に示す $50 \mathrm{t}$ 炬であり, 原料, 操業法も普通法之 ほとんど変わらない，たた，出鋼時の [C] は $0.8 \%$ 以 上と高い. VOD で脱硫はしないので，電炉出鋼時に高 塩基スラグを添加し，出鋼脱硫をする．［S ] は，0.001 〜0.004\% にすることができる.

\subsection{VOD}

設備は表 2 のとおりである.ただし，ポーラスプラグ は, $130 \mathrm{~mm} \phi$ の大径, $2 \sim 6$ 個を用い, Ar 流量は最 大, $48 \mathrm{~N} \mathrm{l} / \mathrm{min} \cdot \mathrm{t}$-steel までの大量供給が可能なものと した. フリーボード $1300 \mathrm{~mm}$ で，スプラッシュの許容 量を十分とつている.

標準的な操業例を図 12 に示す.

\section{3 造 塊}

極低炭素，極低窒素とした鋼は，わずかな供給源から の吸収により，[G]，[N]の増加を招く．ゆ穴に造塊に は細心の注意が払われるが，当社独自の無污染，自動注 入 $\left(\mathrm{KCA}^{13}\right)$ と呼ぶ）造塊法により，注入時の雲囲気は $\mathrm{O}_{2}$ が，0.1\% 以下に確保され，大気からの[N]吸収増 加も，10 ppm までに抑えられている.

\section{4 压延}

高純度高 $\mathrm{Cr} フ ェ$ フィト系ステンレス鋼は，半製品の 段階での脆化が著しく, 分塊から冷間圧延に至る圧延工 程には重大な問題がある，すなわら，粗大凝固組織，冷 却過程での $\chi, \sigma$ 相の析出，さらに $475^{\circ} \mathrm{C}$ 脆性などがそ れで，極めて割れやすい。このために取られた手段は次 


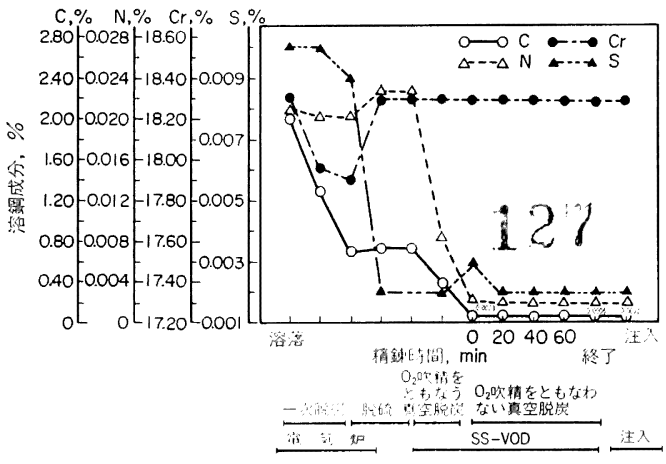

困 $1218 \% \mathrm{Cr}-2 \% \mathrm{Mo}$ 鋼の [C], [N], [Cr], [S] の推移の例
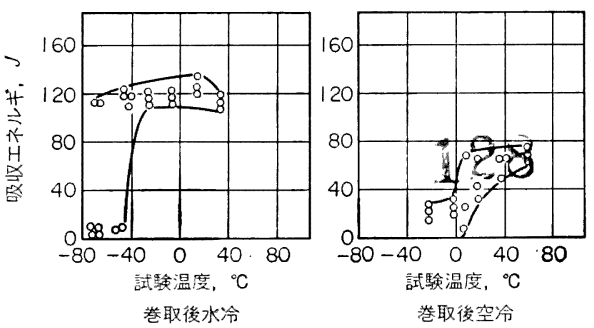

図 13 熱延のままの $30 \% \mathrm{Cr}-2 \% \mathrm{Mo}$ 鋼の衝整特 性におよほす巻取後の水冷の影響 (板厚 $5.0 \mathrm{~mm}$ )

のようなものであり,工程として確立することができた．

（1）熱塊装入： $600^{\circ} \mathrm{C}$ 以上の熱塊装入により，分塊 時の脆性割れは防ぐことができる，ただし，溶製する西 宮工場から，圧延する千葉製鉄所まで，効率のよい保温 ボックスを用いて，海上輸送した。

（2）温片手入れ：分塊スラブは $300 \sim 400^{\circ} \mathrm{C}$ で温片 手入れとした。

（3） ホットコイルの水冷: 熱延終了温度 $900^{\circ} \mathrm{C}$ 以 芸とし，鋼帯はたたちに水槽中で水冷とする.これにて $\sigma, \chi$ 化, $475^{\circ} \mathrm{C}$ 脆化, セパレーションなどは防ぐこと ができる.図 13 は，30\% Cr-2\%Mo 鋼の水冷による顕 著な靶性改善効果を示す。

（4）連続焼なまし：ホットコイルの焼なましは，脆

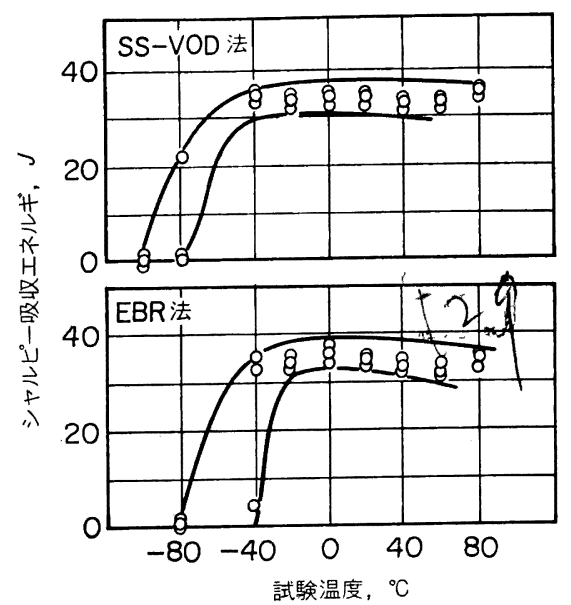

因 $1426 \% \mathrm{Cr}-1 \% \mathrm{Mo}$ 商用 $2 \mathrm{~mm}$ 冷延鋼板の TIG 溶接部の衝繋特性

化を避け，極力短時間とすべきである，連続焼なまし炉 が採用された２6３0\% Cr 鋼の 場合の適正温度は， $1000 \sim 1050^{\circ} \mathrm{C}$ である.

\section{5. 製品の性能}

以上のような製鋼ならびに圧延の技術をもつて製造さ れた高純度フェライト系ステンレス鋼の 1 併としてここ こでは $26 \% \mathrm{Cr}-1 \% \mathrm{Mo}$ 鋼 (SHOMAC - RIVER 26-1) について述べる. 表 7 に本鋼の代表化学成分と，特性を 比較するために用いた材料の化学成分を示す．これらは いずれも商用工程で $2 \mathrm{~mm}$ 厚の冷延板としたものであ る.ここのような材料を使用する場合にはまず溶接部の勒 性が問題となるが，図 14 は，両面フルゴンシールし て，TIG 溶接した溶着鋼のシャルピー衝撃試験結果で あり，EBR 製に比して遷移温度は低く靯性は良好であ る.これらの継手について硫酸一硫酸銅試験を行つた結 果ではいずれも粒界腐食感受性はない，また，図 15 は $10 \%$ 塩化第 2 鉄水溶液に対する対孔食性を示す.

SUS 304L および SUS $316 \mathrm{~L}$ は $40^{\circ} \mathrm{C} て ゙ 24 \mathrm{~h}$ の試験 で孔食を起こすのに対して, SS-VOD法による $26 \% \mathrm{Cr}$ -1\%Mo 鋼は，孔食を全く発生せず，EBR法によるもの

表 7 供試 材 9 化学 組 成 $(\%)$

\begin{tabular}{c|c|c|c|c|c|c|c|c|c|c}
\hline 鋼 & $\mathrm{C}$ & $\mathrm{Si}$ & $\mathrm{Mn}$ & $\mathrm{P}$ & $\mathrm{S}$ & $\mathrm{Ni}$ & $\mathrm{Cr}$ & $\mathrm{Mo}$ & $\mathrm{Nb}$ & $\mathrm{N}$ \\
\hline $\begin{array}{c}\text { SS-VOD 製 } \\
26 \% \mathrm{Cr}-1 \% \text { Mo }\end{array}$ & 0.0022 & 0.33 & 0.08 & 0.018 & 0.004 & 0.17 & 25.90 & 1.20 & 0.16 & 0.0055 \\
\hline $\begin{array}{c}\text { E B R R } \\
26 \% \mathrm{Cr}-1 \% \text { Mo }\end{array}$ & 0.0020 & 0.29 & 0.01 & 0.012 & 0.009 & 0.13 & 26.03 & 1.20 & $\leq 0.01$ & 0.0080 \\
\hline SUS 304L & 0.020 & 0.58 & 1.64 & 0.030 & 0.010 & 10.50 & 18.60 & 0.08 & - & - \\
\hline SUS 316L & 0.012 & 0.84 & 1.76 & 0.037 & 0.005 & 13.77 & 16.40 & 2.29 & - & - \\
\hline
\end{tabular}




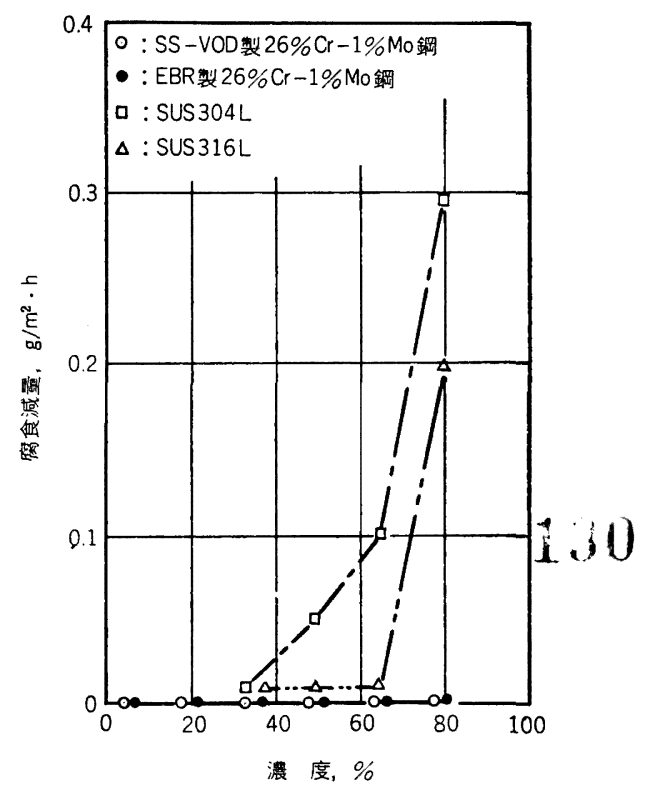

因 15 SS-VOD 製 $26 \% \mathrm{Cr}-1 \% \mathrm{Mo}$ 鋼の沸腾酢酸 水溶液に対する耐食性

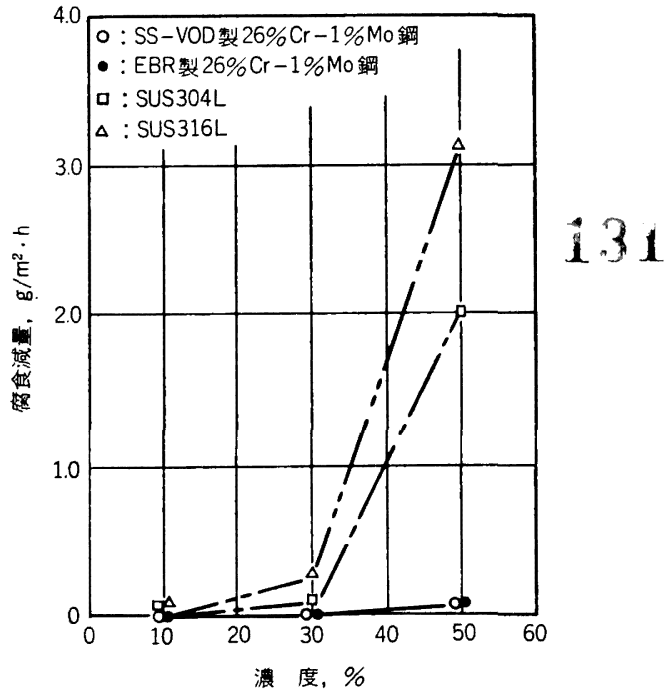

図 $16 \mathrm{SS}-\mathrm{VOD}$ 製 $26 \% \mathrm{Cr}-1 \% \mathrm{Mo}$ 鋼の沸騰苛性 ソーダ水溶液に対する耐食性

と同等である. 図 16 は沸騰硫酸, 酢酸および苛性ソー ダ溶液中での全面腐食性を調べた結果で， $26 \% \mathrm{Cr}-1 \%$ Mo 鋼は，5\% 以下の硫酸中で SUS $316 \mathrm{~L}$ より耐食性 が優れ，また酢酸あるいは苛性ソーダ溶液に対する耐食 性す良好である。この上らな特性を活かし今後酢酸, 乳 酸などの有機酸プラント，隔膜法苛性ソーダプラント， 公害防止プラント拉よび食品プラントなどに用途が開け
るものと思われる。

6. 結

$\mho^{x}$

Ar ガスの大量使用による溶鋼の強摫拌を特㮹とし た，VOD (SS-VOD) 法を開発し，極低炭素, 極低窒 素含有量の高 $\mathrm{Cr} フ ェ$ フィト系ステンレス鋼の量産方式 を確立した。

(1) $2 \sim 6$ 個のポーラスプラグを用い，Ar ガス供 給速度を $10 \sim 48 \mathrm{Nl} / \mathrm{min} \cdot \mathrm{t}$-steel と, 従来法に比べ著し く増した強鯢汼 VOD 処理により，16〜 $26 \% \mathrm{Cr}, 0 \sim 2$ $\% \mathrm{Mo}$ 含有鋼の $\mathrm{C}$ 含有量を $30 \mathrm{ppm}$ 以下, $\mathrm{N}$ 含有量を $40 \mathrm{ppm}$ 以下とすることができた.

（2）脱炭促進の条件は，酸素吹精中（I 期）に強掜 拌するもので, 酸素停止後の真空 CO 脱炭 (II 期) 時 に，スラグ中の $\mathrm{Cr}_{2} \mathrm{O}_{3}$ 含有量を $23 \%$ 以下とし，スラ グのよい流動性を確保する点にある. II 期の Ar ガス流 量なと，他の操業条件の影響は小さい,

(3) 脱窒促進の条件は，処理前 $\mathrm{C}$ 含有量を $0.8 \%$ 以上とし，発生 $\mathrm{CO}$ ガス量を大とするととわに， $a_{\mathrm{N}}$ を 大きくすることである.

（4）圧延時の脆性による割れを回避するためには, 鋼塊とスラクの取扱いは熱塊もしくは熱片で行つたほう がよく，熱延板は水冷する必要がある.

（5）高純度，高 $\mathrm{Cr} フ ェ ラ イ ト$ 系ステンレス鋼の品 質調查を行い，粒界腐食, 靶性などに対する著しい改善 を確認した.

\section{交献}

1) W. A. Matejka: Proc. 4 th Intern. Conf. Vac. Met., Tokyo, Japan, (1973)

2 ) 広瀬洋一, 斎藤 弘, 森村利男, 黒沢正男: 鉄と 鋼，62(1976)，S 748

3 ) 片山裕之, 梶岡博之, 榴富 実, 武田欣明: 鉄之 鋼, 63(1977), p. 2077

4 ) $Y$. Nakamura, $T$. Ohno, and $K$. Segawa: Proc. ICSTIS, Suppl. Trans. ISIJ,11 (1971), p. 456

5 ) J. C. Humbert and $J . F$. Elliott: Trans. Met. Soc. AIME, 218 (1960), p. 1076

6 ) 森 一美, 鈴木 鼎, 中林興栄: 鉄と鋼, 62 (1976)，S 566

7 ) 松永 久: 西山記念技術崢座 第 54,55 回, p. 80

8 ）矢野修也，小口征男，江島涁：私信

9 ) 鈴木 鼎, 森 一美, 伊藤洋平: 鉄と鋼, 55 (1969), p. 13

10) 井上道雄: 電気製鋼, 48(1977), p. 277

11) 沢繁樹, 渋谷正吾, 池田雅宣：日特技報，4 (1968), p. 3

12）たとえば，R. J. Fruehan: Ironmaking and Steelmaking, 3(1976, )p. 33

13）岩润昭二：日本機械振興協会表彰論文集，12 (1977), p. 33 